\title{
OF RAGS AND RICHES: \\ THE BENEFITS OF HEARING JEREMIAH 9:23-24 \\ WITHIN JAMES 1:9-11
}

H.H. Drake Williams, III

\begin{abstract}
Summary
James 1:9-11 encourages the poor and warns the rich about their perceived positions. Despite the apparent simplicity of the teaching, scholars have questioned the identity of the rich person, the nature of the boasting, and the relationship that this teaching has to the other teachings within James 1. Hearing a scriptural echo from Jeremiah 9:23-24 [LXX 9:22-23] within James 1:9-11 can contribute to this discussion. When the context of Jeremiah 9:23-24 and its early interpretations within Jewish literature are heard, they can help identify the rich person in James 1:9-11 as a Christian believer, specify the boasting as a heroic boast, and provide connections with this teaching and others within James 1.
\end{abstract}

\section{Introduction}

James 1:9-11 is the first of a number of passages dealing with issues of wealth and poverty within the epistle of James. ${ }^{1}$ In this passage James encourages the poor person that his position is much higher than he originally considered, and challenges the rich person that his position is much worse than he expected. Despite the apparent simplicity of this text, there are a number of questions that remain.

Firstly, scholars are not in agreement whether the rich person in James 1:9-11 is a Christian believer or not. Those who believe that the rich man is a Christian believer notice the parallelism between 1:9 and 1:10-11 and assume that the idea of brother is continued from 1:9 into $1: 10-11$. The structure of 1:9-10 suggests that the verb for

1 Besides Jas. 1:9-11 see Jas. 1:27; 2:1-7, 14-17; 4:1-3, 13-17; 5:1-11. C.L. Blomberg, Neither Poverty nor Riches: A Biblical Theology of Material Possessions (NSBT; Grand Rapids: Eerdmans, 1999), 148-60. 


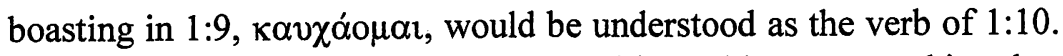
These scholars also see that Christians with wealth are warned in other sections of James (e.g. 2:1-4; 4:13-17). Finally, they note that there is a lengthy Christian history that supports the rich one in 1:10-11 as referring to Christian believers. ${ }^{2}$

Other scholars, however, have recently challenged this position, believing that the rich person is a non-Christian. They notice the

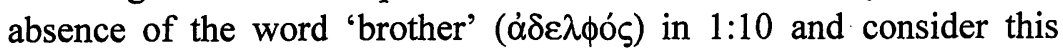
omission to be deliberate. They notice that when the word for the rich one $(\pi \lambda \circ v$ otos) in 1:10 occurs in 2:6-7 that it refers to the nonChristian. The rich non-Christian is in view also from 5:1-5 (cf. 2:1417). Furthermore, they believe that $1: 10-11$ says nothing explicit about the spiritual future for the rich person. The text only notes the destruction that awaits the rich as they go about their business (1:11). They also find the Jewish idea of boasting which is found in 1:9 as referring to eschatological judgement of the non-Christian (cf. Sir. 11:18-19; Aboth 4:4). As a result, these scholars believe that eschatological judgment of non-Christians is envisioned. It is not only the riches of the wealthy that will pass away but also the rich person in the eschatological judgement of God. ${ }^{3}$

A second question regarding James 1:9-11 concerns the idea of 'boasting'. Scholars wonder whether this refers to a heroic boast of a Christian believer or an ironic boast of an unbeliever. If it is a heroic boast then the text calls for the Christian to have a heroic view of their faith. Despite poverty or wealth, Christians ought to see their situations eschatologically - when wealth and poverty will fade away. 4 If the boast is an ironic boast, however, it would be interpreted differently. James would be saying to the rich the equivalent of the following: 'Go ahead and boast. All you have to look forward to is

2 J.B. Adamson, The Epistle of James (Grand Rapids: Eerdmans, 1976), 62-66; D.J. Moo, The Letter of James (Leicester/Grand Rapids: IVP, 1985), 68-69. Cf. J.B. Mayor, The Epistle of St. James. The Greek Text with Introduction, Notes and Comments (Grand Rapids: Zondervan, 1954 reprint), 45-46; F. Mussner, Der Jakobusbrief (HTKNT 13/1; Freiburg: Herder, 1964), 74; J.H. Ropes, A Critical and Exegetical Commentary on the Epistle of St. James (ICC; Edinburgh: T \& T Clark, 1916), 145-46.

3 See R.P. Martin, James (WBC 48; Waco: Word, 1972), 25-26; P.H. Davids, The Epistle of James (Grand Rapids/Carlisle: Eerdmans/Paternoster, 1982), 7677; P.U. Maynard-Reid, Poverty and Wealth in James (Maryknoll: Orbis, 1987), $40-47$.

4 Ropes, James, 145-46; Mayor, James, 43-44; C.L. Mitton, The Epistle of James (Grand Rapids/London: Eerdmans/Marshall, Morgan, \& Scott, 1966), 3637. 
eschatological humiliation at the final judgement. You rich unbelievers have already had your day to boast.' 5

One final issue concerning James 1:9-11 is its relationship to the surrounding verses. Scholars have had the following ideas. Some see it as a maxim that is inserted amongst other sayings like much of the book of James. ${ }^{6}$ Some see 1:9-11 as largely related to the surrounding two or three verses in James 1 like many of the sayings within the first chapter. ${ }^{7}$ Others see $1: 9-11$ as connected thematically to $1: 12.8^{8}$ Others still see 1:9-11 having some thematic relation to texts like 1:2-4 that speak of trial or 1:5-8 that concerns the attainment of wisdom. ${ }^{9}$

These issues can be resolved if one overhears the echo of Jeremiah 9:23-24 within James 1:9-11. This study will suggest responses to these prior issues by examining the presence and function of Jeremiah 9:23-24 within James 1:9-11.

\section{The presence of Jeremiah 9:23-24 in James 1:9-11}

The epistle of James is widely recognised as being influenced by Jewish thinking. The letter cites Scripture in some places (e.g. Pr. 3:34 in Jas. 4:6). James also refers to scriptural examples such as Abraham (Jas. 2:21, 23), Job (Jas. 5:11), and Elijah (Jas. 5:17). The epistle also has strong parallels to Jewish thinking when it addresses issues such as the tongue, humility, and wealth. 10

The influence of Scripture can also be identified within James 1:911. While there is no Scripture citation present or reference to a person from Scripture, there are a number of factors that suggest that an echo of Jeremiah 9:23-24 should be heard within James 1:9-10. Tests for Scripture echoes include the presence of specific vocabulary,

5 M. Dibelius and H. Greeven, James (trans. by M.A. Williams; Hermeneia; Philadelphia: Fortress, 1975), 85; BAGD, 805; cf. E.C. Blackman, The Epistle of James (TBC; London: SCM, 1947), 51.

6 See Dibelius-Greeven who state about the book of James, 'The entire document lacks continuity of thought' (James, 2). They see 1:9-11 as a single unit, $1: 12$ as a solitary aphorism, and $1: 13-15$ as another segment whose placement is due strictly to word linkage (James, 69-71).

7 R.J. Bauckham, James: Wisdom of James, Disciple of Jesus the Sage (London/New York: Routledge, 1999), 63; cf. Davids, James, 75.

8 L.T. Johnson, The Letter of James: A New translation with Introduction and Commentary (AB 37A; New York: Doubleday, 1995) 189.

9 See F. Vouga for a listing of reasons why James turns to the issue of rich and poor at this point in his epistle. F. Vouga, L'épittre de s. Jacques (CNT; Vol. 13a; Geneva: Labor et Fides, 1984), 45-46.

10 Bauckham, James, 35-56, 74-93. 
thematic agreement, the prominence of the Scripture text, and the history of interpretation of the passage in question. ${ }^{11}$ When these tests are applied in this case, there are many reasons to believe that Jeremiah 9:23-24 can be heard within James 1:9-11.

Firstly, there is a notable correspondence in vocabulary. Both passages contain the word $\pi \lambda$ oviøtoc. More importantly, both passages

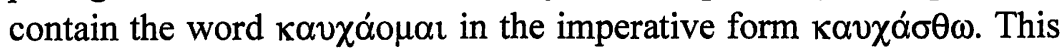
terminology is comparatively rare in Greek literature and in other portions of the New Testament, with the exception of Paul's writings. ${ }^{12}$ When it does occur in other writings (e.g. 1 Sam. 2:10 [LXX], Ode 3:10), these writings are often seen to be dependent upon

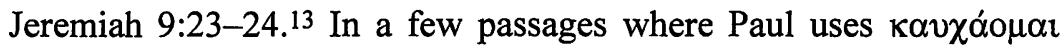
(e.g. 1 Cor. 1:26-31), a large number of scholars have noted that the terminology is dependent upon Jeremiah 9:23-24 (which is, of course, quoted in both 1 Cor. 1:31 and 2 Cor. 10:17). ${ }^{14}$ Thus the presence of

11 For tests used to discern the presence of Scripture in the letters of Paul, consider R.B. Hays, The Echoes of Scripture in the Letters of Paul (New Haven: Yale University Press, 1989), 29-32. See also B.S. Rosner, Paul, Scripture, and Ethics and H.H.D. Williams, The Wisdom of the Wise: The Presence and Function of Scripture within I Cor. 1:18-3:23 (AGJU 49; Brill, 2001), 3.

12 M. Mitchell, Paul and the Rhetoric of Reconciliation: An Exegetical Investigation of the Language and Composition of I Corinthians (Louisville: Westminster/John Knox, 1992), 91.

13 Cf. T. Lewis, 'The Textual History of the Song of Hannah', VT 44 (1994) 1846; E. Kutsch, 'Weisheitsspruch und Prophetenwort: Zur Traditions-geschichte des Spruches Jer 9,22-23', BZ 25 (1981) 161-79.

14 E.g. G.D. Fee, The First Epistle to the Corinthians (NICNT; Grand Rapids: Eerdmans, 1987), 78; R. Harrisville, I Corinthians (ACNT; Minneapolis: Augsburg, 1987), 44; W. Brueggemann, 'The Epistemological Crisis of Israel's Two Histories (Jer. 9:22-23)', in Israelite Wisdom: Theological and Literary Essays in Honor of Samuel Terrien (ed. J.G. Gammie et al.; Missoula: Scholars, 1978), 99; J.M. Gibbs, 'Wisdom, Power and Wellbeing', Studia Biblica 1978. Vol. III. Papers on Paul and Other New Testament Authors (JSNTSup 2; ed. E.A. Livingstone; Sheffield: JSOT, 1980), 120; G. O'Day, 'Jeremiah 9:22-23 and I Corinthians 1:26-31: A Study of Intertextuality', JBL 109 (1990) 259-67; H. Rusche, 'Zum "jeremiahischen" Hintergrund der Korintherbriefe', BZ 31 (1937) 116-19; C.K. Barrett, A Commentary on the First Epistle to the Corinthians (BNTC; London: A. \& C. Black, 1968), 61; C. Stanley, Paul and the Language of Scripture: Citation Technique in the Pauline Epistles and Contemporary Literature (SNTSMS 69; Cambridge: CUP, 1992), 186-188; U. Heckel, 'Jer 9,22f. als Schlüssel für 2 Kor 10-13: Ein Beispiel für die methodischen Probleme in der gegenwärtigen Diskussion über den Schriftgebrauch bei Paulus' Schriftauslegung im antiken Judentum und im Urchristentum (WUNT 73; Eds M. Hengel \& H. Löhr; Tübingen: J.C.B. Mohr [Paul Siebeck], 1994), 206-211; F.S. Malan, 'The Old Testament in I Corinthians', Neo 14 (1981) 140-42. 


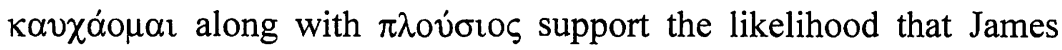
echoes Jeremiah 9:23-24 here. ${ }^{15}$

Secondly, there is a thematic agreement. Both passages have an encouragement for certain people to boast but then an admonition directed at others not to boast. In Jeremiah the faithful can boast in their relationship with the Lord, while in James the humble brother can boast in his eschatological exaltation. In Jeremiah 9:23-24 the rich person, along with the wise and mighty, is encouraged not to boast in his wealth; so also in James the rich person is not to boast in his wealth, only in his ironic humiliation (Jas. 1:10-11). This represents a strong thematic overlap and further supports the presence of an echo of Jeremiah 9:23-24 within James 1:9-11.

Finally, the importance of Jeremiah 9:23-24 for understanding James 1:9-11 has been noticed by a number of commentators. Regarding Jeremiah 9:23-24, W. Holladay states in his commentary on Jeremiah that, 'The Epistle of James also had it in mind.'16 D.J. Moo also pays special attention to the text in his commentary on James noting, "the trajectory of the term [boasting] is set decisively by the famous exhortation in Jeremiah 9:23-24.' 17 Other scholars have also referred to Jeremiah 9:23-24 in their comments on this verse. 18 Thus, there is much to commend the examination of Jeremiah 9:23-24 within James 1:9-11.

\section{Jeremiah 9:23-24 in Early Jewish Literature}

In considering the influence of Jeremiah 9:23-24 on James 1:9-11, an understanding of the context of this Scripture text and its interpretation within early Judaism should be considered to see what influence these have had upon James's understanding.

15 Evidence that Jeremiah was widely known in early Christianity can be found in the numerous citations from and allusions to Jeremiah found throughout the NT. From Jeremiah 9 alone we could note (in addition to the citation already mentioned): Je. 9:10 // Rev. 18:2; Je. 9:11// Mt. 24:2 \& Mk. 13:2; Je. 9:14 // Rev. 8:11; Je. 9:19f. // Lk. 23:28; Je. 9:25f. // Rom. 2:29.

16 See W. Holladay, Jeremiah 1: A Commentary on the Book of the Prophet Jeremiah Chapter 1-25 (Hermeneia; Philadelphia: Fortress, 1986), 318.

17 Moo, James (1985), 65.

18 E.g. Johnson, James, 185. 


\section{A. The Context of Jeremiah 9:23-24}

The context of Jeremiah 9:23-24 discourages boasting in some things and encourages boasting in others. Jeremiah 9:23 discourages boasting in earthly things such as wisdom, power, and riches. Within the broader context of Jeremiah, boasting in human wisdom, strength, and riches is taking pleasure in the wrong commodities that will not save. ${ }^{19}$ In contrast to the improper boast in human resources, Jeremiah 9:24 introduces the rightful object in which God's people should be boasting. They are to boast in knowing and understanding the Lord's future plans when his justice, mercy, and lovingkindness will be revealed. When the book of Jeremiah is examined, these ideas are often found when God's overall plan, his new covenant, or his coming king will be revealed. ${ }^{20}$

The broader context of Jeremiah 9:23-24 also reveals that a reversal of roles is to be found surrounding the ideas of boasting. Within Jeremiah 9:17-22, those who were of no account are now understood to be the representatives of a new order pronouncing judgement upon Judah. The wailing women who are summoned for the lament indicate this. Within the broader context of Jeremiah, women are portrayed to be weak and inconsequential, ${ }^{21}$ yet in the surrounding context of Jeremiah 9:23-24 they alone are summoned to hear the word of the Lord as is indicated by the change in gender from masculine to feminine commands (Je. 9:17-21). ${ }^{22}$ They also are now understood to be the only wise ones and in this section exclusively pass on the words of judgement (Je. 9:17, 21). ${ }^{23}$ Thus, those of little consequence are deemed to be of great significance within the broader context of Jeremiah 9:23-24.

\section{B. Jeremiah 9:23-24 in Early Jewish Literature}

Jeremiah 9:23-24 [LXX 9:22-23] is quoted in the Septuagint version of 1 Sam. 2:10 ( $\mathrm{LXX}=$ Ode 3:10). The presence of Jeremiah 9:23-24 has also been noticed in Pseudo-Philo's Liber Antiquitatum Biblicarum 50:2; in Pseudo-Phocylides 1. 53; and in Sirach 11:6; 24:1-

19 Cf. Je. $4: 22 ; 5: 26-28 ; 8: 8,9 ; 10: 9 ; 14: 9 ; 16: 21 ; 17: 11 ; 18: 18 ; 23: 10 ; 49: 35$; $50: 35 ; 51: 30,57$.

20 E.g. Je. $23: 5 ; 31: 3 ; 33: 15$.

21 Note that one characteristic evident of women throughout Jeremiah is their weakness. A prophesied judgment upon the strong is that their actions will be like women in labor (Je. 48:41; 49:22, 24; 50:37, 43; 51:30).

22 P. Craigie, P. Kelley, \& J. Drinkard, Jeremiah 1-25 (WBC; Dallas: Word, 1991), 149-50.

23 D.R. Jones, Jeremiah (NCB; Grand Rapids: Eerdmans, 1982), 168. 
$7 ; 39: 7-8 .{ }^{24}$ Its influence can also be seen in other passages in early Jewish literature such as $1 Q S$ i $5-6$, viii $1-2,11 Q^{a}$ xviii 9-16, 4Q185 ii 8-13, Pss. Sol. 17:1, Jos. Asen. 21:11-21; Jdt. 9:7-9; 15:910; Bar. 3:9-4:4.25

Many of these early Jewish texts serve to reinforce what the context of Jeremiah 9:23-24 has portrayed. The following is a sample of the some of the closest relationships that Jeremiah 9:23-24 has with early Jewish literature.

\section{Septuagint}

Septuagintal adaptations are inconsequential within the Greek rendering of this particular passage in Jeremiah. Two places within the Septuagint where Jeremiah 9:23-24 does appear are of significance. In 1 Samuel 2:10 (= Ode 3:10), the words of Jeremiah 9:23-24 occur within the song of Hannah, which proclaims Hannah's joy over the birth of her son Samuel and the judgement of God's enemies. In verse 10 , Jeremiah's warnings to the wise, powerful and rich preface Hannah's declaration of judgement-the Lord will shatter those who oppose him and bring thunder against his enemies as he judges the earth.

In addition to the idea of judgement, a prominent theme in 1 Samuel 2:10 (= Ode 3:10) is the triumphant reversal of status. The entire song of Hannah speaks of this reversal of status. Hannah's barren status has been reversed, and her song also speaks of other reversals. The weak triumph over the strong, the hungry over the full, and the barren one over the productive (1 Sam. 2:4-5). This reversal is seen presently in Hannah's song and will be expected ultimately at the end of time.

\section{Liber Antiquitatum Biblicarum}

$L A B$ 50-64 is largely dependent upon 1 Samuel, and a reference to Jeremiah 9:23-9:24 is found in $L A B$ 50:2.26 The words are used by

24 U. Heckel, 'Jer 9.22f. als Schlüssel für 2 Kor 10-13', 209. J. Schreiner notes the influence of Je. 9:23-24 [LXX 9:22-23] in the book of Sirach, 'Jeremia 9, 2223 als Hintergrund des paulinischen "Sich-Ruhmens" in Neues Testament und Kirche, Festschrift für Rudolf Schnackenburg (Ed. J. Gnilka; Freiburg: Herder, 1974), 530-42.

25 See further Williams, The Wisdom of the Wise, 110-24.

26 Although the date of Liber Antiquitatum Biblicarum is uncertain, it clearly contains early traditions. For discussion see D.J. Harrington, 'Pseudo-Philo' The Old Testament Pseudepigrapha (ed. by J.H. Charlesworth; New York: Doubleday, 1985), 296-303. 
Peninnah as a taunt against Hannah, 'Let Hannah not boast in her appearance; but she who boasts let her boast when she sees her offspring before her.' 27 Due to the idea of boasting and the similarity that $L A B$ 50:2 has with 1 Sam. 2:10 ( $\mathrm{LXX}=$ Ode 3:10), it is likely that an allusion to Jeremiah 9:23-24 is present here.

The use of Jeremiah 9:23-24 in Liber Antiquitatum Biblicarum particularly portrays a false object for boasting, not boasting in appearances. Hannah and Peninnah are to boast in the result of prominent sons. While this initially may be seen as a disadvantage to Hannah who does not have a son when Peninnah taunts her, Hannah's trust in the Lord results in her son Samuel becoming an idyllic leader within Liber Antiquitatum Biblicarum ( $L A B$ 50:5, 8; 51:2-7; cf. 49:8). ${ }^{28}$ As a result, Hannah's status is reversed from one who is lowly to one who is exalted.

\section{Pseudo-Phocylides}

The command in Ps. Phoc. 1. 53: 'Do not pride yourself on wisdom nor on strength nor on riches' seems to be a clear echo of the triad of wisdom, strength, and riches, found in Jeremiah 9:23 [LXX 9:22]. ${ }^{29}$ Ideas of future judgement by the Lord are found in close proximity to this command. Line 52 indicates that each man's intention will be examined. Line 54 indicates that God alone is wise, mighty, and rich. Thus Jeremiah 9:23 is once again placed within the context of future judgement in early Jewish literature.

\section{Sirach}

Sirach 11:1-6 contains some similar ideas as Jeremiah 9:23 [LXX

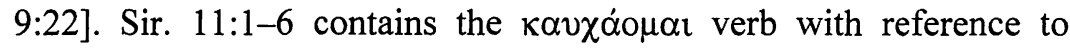
riches, which in this case is expressed in clothing. ${ }^{30}$ It reads,

The wisdom of the humble lifts their heads high, and seats them among the great. Do not praise individuals for their good looks, or loathe anyone because of appearance alone. The bee is small among flying creatures, but

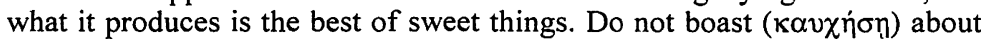
wearing fine clothes, and do not exalt yourself when you are honored; for the works of the Lord are wonderful, and his works are concealed from humankind. Many kings have had to sit on the ground, but one who was

27 U. Heckel, 'Jer 9.22f. als Schlüssel für 2 Kor 10-13', 209.

28 G.W. Nickelsburg, 'Good and Bad Leaders in Pseudo-Philo's Liber Antiquitatum Biblicarum', Ideal Figures in Ancient Judaism (SCSt 12; ed. G.W. Nickelsburg and J.J. Collins; Chico: Scholars, 1980), 54-55, 58-59.

29 U. Heckel, 'Jer 9.22f. als Schlüssel für 2 Kor 10-13', 209; OTP, II:576.

30 Cf. U. Heckel, 'Jer 9.22f. als Schlüssel für 2 Kor 10-13', 209. 
never thought of has worn a crown. Many rulers have been utterly disgraced, and the honored have been handed over to others.

The ideas associated with boasting are of note. There is a contrast established between human boasting and the works of God: boasting in riches is deplored and is contrasted with the works of God which are wonderful and concealed from humanity. Sir. 11:5-6 also expresses a reversal of roles: the one who is of no account is exalted while kings and rulers are humbled. ${ }^{31}$ Greatness is ascribed to the small, diligent bee and the humble (Sir. 11:1, 3).

\section{Summary}

These early Jewish texts which allude to Jeremiah 9:23-24 serve to reinforce what the context of Jeremiah 9:23-24 has already emphasised. The text is regularly used to cause God's people to reevaluate their understanding of wisdom, strength, and riches. Those who appear to be lacking in earthly resources but who have faith in God are the ones whose fortunes will be reversed. Judgement will come in the future to those trusting in their own human wisdom, strength, and riches.

\section{Hearing Jeremiah 9:23-24 in James 1:9-11}

There are a number of benefits of hearing an echo of Jeremiah 9:2324 and its early Jewish interpretations within James 1:9-11. Firstly, it can help with the identification of the rich and the poor person. In the greater context of Jeremiah 9:23-24 and the appearances of Jeremiah 9:23-24 within early Jewish literature, God's people were always indicated. These texts use the theme of boasting and other ideas which stem from Jeremiah 9:23-24 to apply to God's people.

This background supports the historic position that within James 1.9-11 both the rich and the poor person should be seen as part of God's people - the rich among God's people are being warned and the poor among God's people are being encouraged. This fits James' purpose in other passages within the epistle to encourage God's people not to be allured by wealth (2:1ff.; $4: 13 \mathrm{ff}$.). While other texts within James address the rich as non-Christians (e.g. 2:14-17; 5:1-5), his encouragement in other places is for the Christian to find one's true wealth in the Lord and not to adapt the ways of the world (cf. 2:5;

31 P.W. Skehan and A.A. DiLella, The Wisdom of Ben Sira (ABC 39; New York: Doubleday \& Co., 1987), 233-34. 
4:4).32 Thus when the ideas from Jeremiah 9:23-24 are credited to the

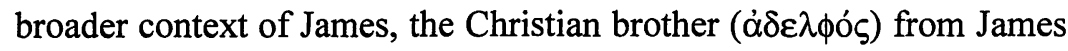
1:9 should be considered as extending to $1: 10$.

Secondly, hearing an echo of Jeremiah 9:23-24 can help make sense of the boasting in James 1. It favours a heroic boast of believers over an ironic boast. When Jeremiah 9:23-24 is heard within James 1:9-11, it encourages God's people to look towards the future when riches will mean little and being in God's plan will mean a great deal. Hearing Jeremiah 9:23-24 also encourages hearing a reversal of roles of God's people when those who are poor will be rich in the Lord.

Finally, hearing an echo of Jeremiah 9:23-24 within James 1:9-11 helps to place these verses from James within the broader context of the epistle of James. Since boasting from Jeremiah 9:23-24 has eschatological ideas associated with it, it causes the reader to hear James 1:9-11 in agreement with James 1:12 when the crown of life is given at the end of time. ${ }^{33}$ James 1:9-11 can also be heard in relation to the future benefits that come from trials in James 1:2-4. A connection with James 1:5-8 and its concern for wisdom can also be perceived when the wise women from the broader context of Jeremiah 9:23-24 are considered. Hearing Scripture, then, within James 1:9-11 provides connections between James $1: 9-11$ and the surrounding context of James 1.

32 It is likely that the rich from the world were pressuring God's people; see Davids, James, 28-34.

33 Johnson notes that the 'crown of life' could be understood as 'the crown that signifies elevation into the future life of God' (cf. 2 Tim. 4:8; Jas. 2:5; 1 Pet. 5:4; Rev. 2:10), James, 188. 